\title{
Ultrastructural Localization of the CB1 Cannabinoid Receptor in $\mu$-Opioid Receptor Patches of the Rat Caudate Putamen Nucleus
}

\author{
José J. Rodríguez, ${ }^{1}$ Kenneth Mackie, ${ }^{2}$ and Virginia M. Pickel ${ }^{1}$ \\ 1 Department of Neurology and Neuroscience, Division of Neurobiology, Weill Medical College of Cornell University, New \\ York, New York 10021, and 2Department of Anesthesiology, University of Washington, Seattle, Washington 98195
}

\begin{abstract}
Cannabinoids and opioids are widely consumed drugs of abuse that produce motor depression, in part via respective activation of the cannabinoid subtype 1 receptor (CB1R) and the $\mu$-opioid receptor $(\mu \mathrm{OR})$, in the striatal circuitry originating in the caudate putamen nucleus (CPN). Thus, the CB1R and $\mu \mathrm{OR}$ may show similar targeting in the CPN. To test this hypothesis, we examined the electron microscopic immunocytochemical labeling of CB1R and $\mu \mathrm{OR}$ in CPN patches of rat brain. Of the CB1Rlabeled profiles, $34 \%$ (588) were dendrites, presumably arising from spiny as well as aspiny-type somata, which also contained CB1R immunoreactivity. In dendrites, CB1R often was localized to nonsynaptic and synaptic plasma membranes, particularly near asymmetric excitatory-type junctions. Almost one-half of the CB1R-labeled dendrites contained $\mu \mathrm{OR}$ immunoreactivity, whereas only $20 \%$ of all $\mu$ OR-labeled dendrites expressed CB1R. Axons and axon terminals as well as abundant glial
\end{abstract}

$\Delta^{9}$-Tetrahydrocannabinol (THC), the major psychoactive component of the marijuana plant (Cannabis sativa), and the two well characterized endogenous brain cannabinoids, anandamide and sn-2 arachidonylglycerol (Devane et al., 1992; Stella et al., 1997), elicit their central actions mainly via the activation of subtypespecific cannabinoid receptors (Howlett, 1985; Little et al., 1988). Activation of the CB1 brain cannabinoid receptor (CB1R) prominently decreases motor activity (Devane et al., 1988; Howlett et al., 1990; Matsuda et al., 1990; Rinaldi-Carmona et al., 1994; Compton et al., 1996). The motor inhibition produced by CB1R activation has been attributed to functional sites within striatopallidal projections arising from GABAergic spiny neurons located within the caudate putamen nucleus (CPN). Opiates active at the $\mu$-opioid receptor ( $\mu \mathrm{OR})$ also produce potent motor inhibition and share many pharmacological and addictive properties with cannabinoids (Manzanares et al., 1999). Furthermore, the endogenous opioid peptide, enkephalin, is present in striatopallidal projection neurons, many of which express CB1R mRNA (Hohmann and Herkenham, 2000; Page et al., 2000). Together, these observations suggest that $\mathrm{CB} 1 \mathrm{R}$ and $\mu \mathrm{OR}$ show similar targeting in the CPN.

CB1R distribution appears rather uniform throughout the rat

Received Sept. 29, 2000; revised Nov. 2, 2000; accepted Nov. 3, 2000.

This work was supported by National Institute on Drug Abuse Grants DA04600 (to V.M.P.) and DA00256 and DA11322 (to K.M.); National Institute of Mental Health Grants MH40342 and MH 00078 (to V.M.P.); and Heart and Lung Institute Grant HL18974 (to V.M.P.).

Correspondence should be addressed to Dr. V. M. Pickel, Department of Neurology and Neuroscience, Division of Neurobiology, Weill Medical College of Cornell University, 411 East 69th Street, New York, NY 10021. E-mail: vpickel@mail.med.cornell.edu.

Copyright (C) 2001 Society for Neuroscience $\quad 0270-6474 / 01 / 210823-11 \$ 15.00 / 0$ processes also showed plasmalemmal CB1R and were mainly without $\mu \mathrm{OR}$ immunoreactivity. Many CB1R-labeled axon terminals were small and without recognizable synaptic junctions, but a few also formed asymmetric, or more rarely symmetric, synapses. The CB1R-labeled glial processes were often perivascular or perisynaptic, surrounding asymmetric excitatory-type axospinous synapses. Our results show that in CPN patches CB1R and $\mu \mathrm{OR}$ are targeted strategically to some of the same postsynaptic neurons, which may account for certain similarities in motor function. Furthermore, they also provide evidence that CB1R may play a major role in the modulation of presynaptic transmitter release and glial functions that are unaffected in large part by opioids active at $\mu \mathrm{OR}$ in CPN.

Key words: marijuana; morphine; striatum; striosome; glutamate; glia; ultrastructure and primate $\mathrm{CPN}$, as seen by light microscopic ligand-binding autoradiography, in situ mRNA hybridization, and immunocytochemistry (Herkenham et al., 1990, 1991b,c; Mailleux and Vanderhaegen, 1992; Matsuda et al., 1993; Pettit et al., 1998; Tsou et al., 1998; Ong and Mackie, 1999). Although the electron microscopic distribution of the $\mathrm{CB} 1 \mathrm{R}$ has not been examined in the CPN, studies in other brain regions suggest preferential distribution of the receptor at presynaptic sites in inhibitory neurons (Katona et al., 1999). In contrast, the $\mu \mathrm{OR}$ in $\mathrm{CPN}$ has a prominent patch-like localization and a major subcellular distribution in dendrites and dendritic spines in this region (Herkenham and Pert, 1982; Mansour et al., 1987; Wang et al., 1996, 1999). The CPN patch compartments differ from the surrounding matrix in their relative size and function. The $\mu \mathrm{OR}$-enriched patches have a small volume and extensive anatomical connections with limbic-related brain regions, including those serving reward-related activities (Gerfen, 1984; Donoghue and Herkenham, 1986; Ragsdale and Graybiel, 1988; Johnston et al., 1990; White and Hiroi, 1998). The matrix comprises $>85 \%$ of the CPN and is associated more prominently with motor functions (Gerfen, 1984; Donoghue and Herkenham, 1986; Johnston et al., 1990). Thus the patch regions are likely to be important sites for reinforced reward-related motor activity. In the present study we examined the electron microscopic immunocytochemical localization of CB1R and $\mu \mathrm{OR}$ in the CPN patches of rat brain. We sought to determine (1) the sites for functional activation and intracellular trafficking of the CB1R and (2) potential overlap in the distribution between CB1R and $\mu \mathrm{OR}$ in single neurons that might contribute to their similarities in motor function. Together, our results show that the $\mathrm{CB} 1 \mathrm{R}$ is present in both neurons and 
glia in the CPN and that select populations of neurons in the patch regions coexpress $\mathrm{CB} 1 \mathrm{R}$ and $\mu \mathrm{OR}$.

\section{MATERIALS AND METHODS}

\section{Tissue preparation}

The animal protocols that were used in this study adhere to National Institutes of Health Guidelines for the Care and Use of Laboratory Animals in Research and were approved by the Animal Care Committee at Weill Medical College of Cornell University. Adult male Sprague Dawley rats (300-400 gm; Taconic, Germantown, NY) were anesthetized deeply with sodium pentobarbital $(100 \mathrm{mg} / \mathrm{kg}$, i.p.). The brains of these animals were fixed by aortic arch perfusion with $50 \mathrm{ml}$ of $3.8 \%$ acrolein (Polysciences, Warrington, PA) in a solution of $2 \%$ paraformaldehyde and 0.1 $\mathrm{M}$ phosphate buffer (PB), $\mathrm{pH} 7.4$, followed by $250 \mathrm{ml}$ of $2 \%$ paraformaldehyde. The brains were removed from the cranium and cut into 4-5 $\mathrm{mm}$ coronal slabs of tissue containing the entire rostrocaudal extent of the $\mathrm{CPN}$. Then this tissue was postfixed for $30 \mathrm{~min}$ in $2 \%$ paraformaldehyde and sectioned at 30-40 $\mu \mathrm{m}$ on a Vibratome (Leica, Deerfield, IL) (Leranth and Pickel, 1989). To remove the excess of reactive aldehydes, we treated the sections with $1 \%$ sodium borohydride in $0.1 \mathrm{M}$ PB for 30 min. Then the tissue sections were freeze-thawed to optimize the penetration of immunoreagents. For this procedure the sections were (1) incubated in cryoprotectant solution containing $25 \%$ sucrose and $3.5 \%$ glycerol in $0.05 \mathrm{M} \mathrm{PB}, \mathrm{pH} 7.4$, and (2) rapidly immersed in chloriduofluoromethane, followed by liquid nitrogen and room temperature $\mathrm{PB}$. Then the sections were rinsed in $0.1 \mathrm{M} \mathrm{PB}$, followed by $0.1 \mathrm{M}$ Tris-buffered saline (TBS), $\mathrm{pH}$ 7.6.

\section{Antibodies}

A polyclonal rabbit antiserum was generated by using the $\mathrm{N}$ terminus 77 amino acid residues of the cloned rat CB1R fused to glutathione $S$-transferase (GST) as the antigen (Twitchell et al., 1997). In Western blot analysis this CB1R antiserum recognized a major band of $63 \mathrm{kDa}$ in the rat cortex, hippocampus, striatum, and cerebellum corresponding to the predicted size of CB1R (Matsuda et al., 1990; Tsou et al., 1998). The immunolabeling with this CB1R antiserum was removed selectively by preincubation with the immunizing protein (Twitchell et al., 1997; Tsou et al., 1998). Furthermore, the labeling was seen in CB1R-transfected, but not in nontransfected, AtT20 cells (Mackie et al., 1995; Tsou et al., 1998). In addition, the immunolabeling pattern that uses this CB1R antiserum is similar to that of the corresponding mRNA and ligandbinding sites in brain (Matsuda et al., 1990; Herkenham et al., 1991a-c; Mailleux and Vanderhaegen, 1992).

A polyclonal guinea pig antiserum directed against a synthetic peptide (NHQLENLEAETAPLP) corresponding to the C terminus (amino acids 384-398) of the cloned rat $\mu$ OR1 was obtained from Chemicon (Temecula, CA). The pattern of labeling obtained with this antibody is consistent with $\mu \mathrm{OR}$ autoradiographical localization and with the immunolabeling observed with other $\mu \mathrm{OR}$ antibodies (Arvidsson et al., 1995; Mansour et al., 1995; Wang et al., 1996, 1999). In addition, preadsorption of the $\mu \mathrm{OR}$ antiserum with the specific peptide sequence (18 $\mu \mathrm{g} / \mathrm{ml})$ resulted in the loss of immunoreactivity.

\section{Immunocytochemistry}

Single labeling. For this procedure the vibratome sections were incubated first for $30 \mathrm{~min}$ in $0.5 \%$ bovine serum albumin in TBS to minimize nonspecific labeling. Then the tissue sections were incubated for $48 \mathrm{hr}$ at $4^{\circ} \mathrm{C}$ in $0.1 \%$ bovine serum albumin in TBS containing rabbit polyclonal antiserum for CB1R at 1:2000 (for immunoperoxidase labeling) or at 1:500 (for immunogold labeling). Subsequently, the CB1R antibody was detected by using the pre-embedding immunoperoxidase or immunogold-silver methods (Chan et al., 1990). For immunoperoxidase labeling the sections then were washed and placed in (1) 1:400 dilution of biotinylated donkey anti-rabbit (Jackson ImmunoResearch, West Grove, PA) immunoglobulin (IgG) and (2) 1:200 dilution of biotin-avidin complex from the Elite kit (Vector Laboratories, Burlingame, CA). All antisera dilutions were prepared in TBS, and the incubations were performed at room temperature. The peroxidase reaction product was visualized by incubation in a solution containing $0.022 \%$ of $3,3^{\prime}$ diaminobenzidine (DAB; Aldrich, Milwaukee, WI) and $0.003 \% \mathrm{H}_{2} \mathrm{O}_{2}$ in TBS for $6 \mathrm{~min}$.

For immunogold-silver labeling the sections were rinsed in $0.01 \mathrm{M}$ PBS, $\mathrm{pH} 7.4$, and blocked in $0.8 \%$ BSA and $0.1 \%$ gelatin in PBS for 10 min. After this incubation the sections were processed for $2 \mathrm{hr}$ in a 1:50 dilution of goat anti-rabbit IgG conjugated with $1 \mathrm{~nm}$ of colloidal gold (Amersham, Arlington Heights, IL) in BSA/gelatin and then rinsed in BSA/gelatin and PBS. The bound gold particles were secured in the tissue by placing the sections in $2 \%$ glutaraldehyde in $0.01 \mathrm{M}$ PBS for 10 $\mathrm{min}$. Then these sections were washed in $0.2 \mathrm{M}$ citrate buffer and reacted for 6-8 min with a silver enhancement solution (IntenSE kit, Amersham). The silver reaction was stopped by successive rinses in citrate buffer.

Dual labeling. For immunocytochemical localization of CB1R and $\mu$ ORs, previously prepared sections through the CPN were processed for combined immunoperoxidase and immunogold-silver labeling (Chan et al., 1990). The primary antibodies against CB1R and $\mu \mathrm{OR}$ were raised in rabbits and guinea pig, respectively; hence they could be distinguished by appropriate species-specific secondary antibodies. Peroxidase and gold markers were switched in alternate sections to maximize the detection of either antigen with methods differing in resolution and sensitivity (Leranth and Pickel, 1989). Sections were incubated for $48 \mathrm{hr}$ at $4^{\circ} \mathrm{C}$ in $0.1 \%$ bovine serum albumin in TBS containing (1) rabbit polyclonal antiserum for CB1R (1:2000 dilution for immunoperoxidase and 1:500 dilution for immunogold) and (2) guinea pig polyclonal antiserum for $\mu \mathrm{OR}$ (1:1000 dilution for immunoperoxidase and 1:200 dilution for immunogold). After the incubation with these primary antisera the sections were processed for peroxidase first and then for gold detection, as described above. Biotinylated donkey anti-rabbit IgG (1:400; Jackson ImmunoResearch) or gold-conjugated goat anti-rabbit IgG (1:50; Amersham) was used for CB1R labeling. Goat anti-guinea pig IgG, which either was biotinylated (1:400; Vector Laboratories) or was conjugated with gold (1:50; Electron Microscopy Sciences, Ft. Washington, PA), was used for $\mu$ OR labeling.

\section{Electron microscopic examination and nomenclature}

For electron microscopy the immunolabeled tissue sections were rinsed in $0.1 \mathrm{M} \mathrm{PB}, \mathrm{pH} 7.4$, and then postfixed for $1 \mathrm{hr}$ in $2 \%$ osmium tetroxide in PB. They subsequently were dehydrated through a graded series of ethanols and propylene oxide before being embedded in Epon 812 between sheets of Aclar plastic (Allied Signal, Pottsville, PA) (Leranth and Pickel, 1989). Ultrathin sections were cut with a diamond knife (Diatome, Fort Washington, PA) and collected on copper mesh grids. The sections on grids were counterstained with uranyl acetate and lead citrate (Reynolds, 1963) and were examined with a Philips CM-10 electron microscope (Philips, Mahwah, NJ).

Labeled profiles were classified as somata, dendrites, dendritic spines, unmyelinated axons, axon terminals, and glia according to their morphological features, as defined by Peters et al. (1991). Somatic profiles were identified by the presence of nuclei and abundant cytoplasm. Dendrites were recognized by the presence of afferent axon terminals and/or content of endoplasmic reticulum. The dendritic profiles were differentiated from dendritic spines on the basis of their larger size and greater abundance of mitochondria and other organelles. As compared with spines, dendrites also less frequently received input from axon terminals forming asymmetric excitatory-type synapses. Dendritic spine heads were usually larger than small axonal or glial profiles and had a more rounded, bulbous shape. Unmyelinated axons were $<0.2 \mu \mathrm{m}$ in diameter and contained microtubules and a few small vesicles. Although unmyelinated axonal profiles were recognized easily in bundles, individual axons were sometimes difficult to distinguish from spine necks. In this case they were included in the category of unidentified small profiles. We defined axon terminals as being profiles between 0.2 and $1.5 \mu \mathrm{m}$ in diameter and containing many small synaptic vesicles (SSVs). Synapses were defined as symmetric when having thin presynaptic and postsynaptic densities or as asymmetric when having a thin presynaptic and a thick postsynaptic membrane specialization. Perforated synapses were defined as those asymmetric synapses with a notable discontinuity $(>50 \mathrm{~nm})$ in the electron density of the postsynaptic junction (Greenough et al., 1978). Glial profiles were characterized by their irregular shape and investment of neighboring neurons. In some cases the intermediate filaments also were used to identify astrocytic profiles.

Immunogold-silver labeling for each receptor antigen was characterized as either plasmalemmal or cytoplasmic. The former would reflect potential functional sites accessible to extracellular ligands, whereas the later might reflect internalized or newly synthesized receptor protein (Boudin et al., 1998). A profile was considered to be immunogold-silverlabeled when (1) two or more gold particles were observed within the cytoplasm independently of their subcellular location or (2) at least one 
gold particle was observed on the plasma membrane (Garzón et al., 1999).

\section{Data analysis}

The ultrastructural analysis was performed exclusively on the most superficial portions of the tissue in contact with the embedding plastic to minimize artificial differences in labeling attributed to potential differences in the penetration of reagents (Pickel et al., 1992). Regions used for this analysis were chosen on the basis of the presence of CB1R and/or $\mu \mathrm{OR}$ immunoreactivity and the morphological integrity of the tissue. The labeled profiles were examined in 16 vibratome sections obtained from three animals that were taken through the CPN at a level 0.7-1.7 $\mathrm{mm}$ anterior to bregma, according to the rat brain atlas of Paxinos and Watson (1986). Three sections from each animal were collected for quantification purposes. All immunoreactive processes $(n=2316)$ were counted in randomly sampled electron micrographs taken at magnifications of 5200-21,000 $\times$ from an area of $8113.90 \mu \mathrm{m}^{2}$, with an area of at least $2450.68 \mu \mathrm{m}^{2}$ in each animal. Random sampling was assured by using an automated specimen relocation system on the CM-10 electron microscope to identify fields for analysis, which were stored at a magnification of $3900 \times$. These sections were processed with immunoperoxidase for $\mu \mathrm{OR}$ and with immunogold for the localization of CB1R. Sections processed with reversal of the markers were examined to confirm the cellular distributions of the receptors.

The electron micrographs used for the figures were scanned on a PowerMacintosh 9600/300 Computer (Apple Computers, Cupertino, CA) with an AGFA Duoscan T1200 (Agfa-Gevaert, Montsel, Belgium) in combination with Fotolook (Agfa-Gevaert) and Adobe Photoshop (version 4.0; Adobe Systems, Mountain View, CA) software. To build and label the composite illustrations, we used QuarkXpress (version 3.32; Quark, Denver, CO) and Adobe Illustrator (version 6.0; Adobe Systems) software.

\section{RESULTS}

CB1R-like immunoreactivity (CB1R-LI) was seen by light microscopy within cells in both matrix and patch compartments of the CPN, whereas $\mu$ OR-like immunoreactivity ( $\mu$ OR-LI) was present almost exclusively in patches (Fig. 1). Many of the CB1Rlabeled cells had round nuclei and multiple branched processes that are typical of spiny neurons. Other CB1R-labeled cells resembled perivascular astrocytes (Fig. 1). In electron micrographs from CPN patches, structures containing CB1R-LI represented $25 \%$ (588 of 2316) of the total labeled profiles, whereas $75 \%$ (1728 of 2316) contained exclusively $\mu$ OR-LI. Sixty-four percent (374 of 588) of the CB1R-labeled profiles were neuronal, and the remaining were glial or unidentified. Twenty-six percent (154 of 588 ) of the total CB1R-labeled profiles, mainly dendritic, also contained $\mu \mathrm{OR}-\mathrm{LI}$ within the CPN patches (Fig. $2 A$ ). Dendrites and dendritic spines also comprised $60 \%$ (1121 of 1882) of the total $\mu \mathrm{OR}$-labeled profiles, and the remaining profiles were primarily axons and axon terminals (Fig. 2B). Many more glial processes expressed CB1R than $\mu \mathrm{OR}$ despite the greater abundance of $\mu \mathrm{OR}$-labeled profiles in the $\mathrm{CPN}$ patches.

\section{Somatodendritic CB1R distribution and relation with $\mu$ OR}

In the CPN, CB1R-LI was localized discretely within the cytoplasm of many somata containing round nonindented and a few indented nuclei, which are typical of spiny and aspiny neurons, respectively (DiFiglia et al., 1980). In somata the CB1R labeling was distributed on selective segments of plasma membranes and along membranes of the trans-Golgi lamellae near the nucleus (Fig. 3A). The plasmalemmal CB1R-LI often was present on portions of the membrane apposed to small axons or terminals without recognizable synaptic specializations (Fig. $3 A$ ). Occasionally, CB1R-LI also was seen within multivesicular bodies and/or endosome-like organelles (Fig. $3 B$ ). In sections processed for dual labeling almost one-half of the CB1R-immunoreactive
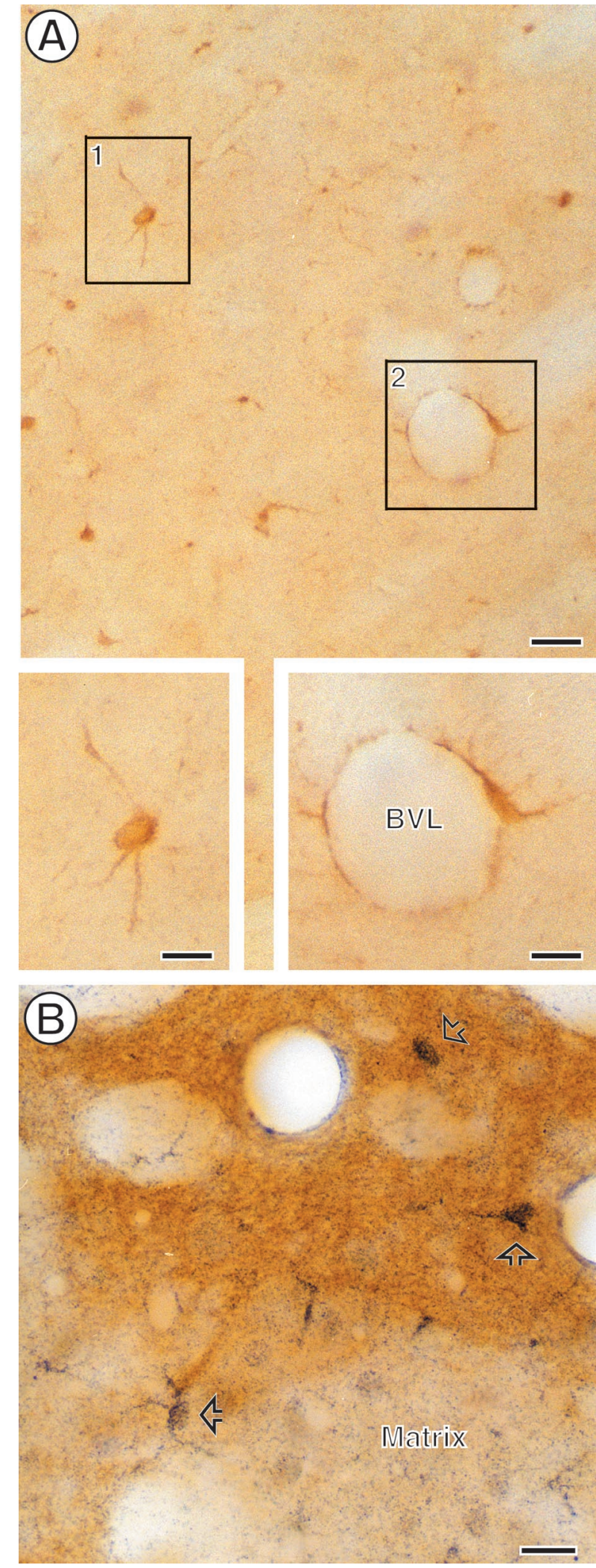

Figure 1. Photomicrographs showing striatal CB1R and $\mu \mathrm{OR}$. $A$, Immunoperoxidase labeling for CB1R in a medium-sized spiny neuron (inset, boxed region 1 ) and in a perivascular glial cell (inset, boxed region 2). B, Immunogold labeling (open arrows) for CB1R within a striatal patch, which shows brown peroxidase reaction product identifying $\mu \mathrm{OR}$ immunoreactivity. Gold CB1R labeling also is seen in numerous cells and processes within the matrix compartment, which is without $\mu \mathrm{OR}$ peroxidase reaction product. Scale bars: $A, 50 \mu \mathrm{m}$; insets in $A, B, 25 \mu \mathrm{m}$. 
A

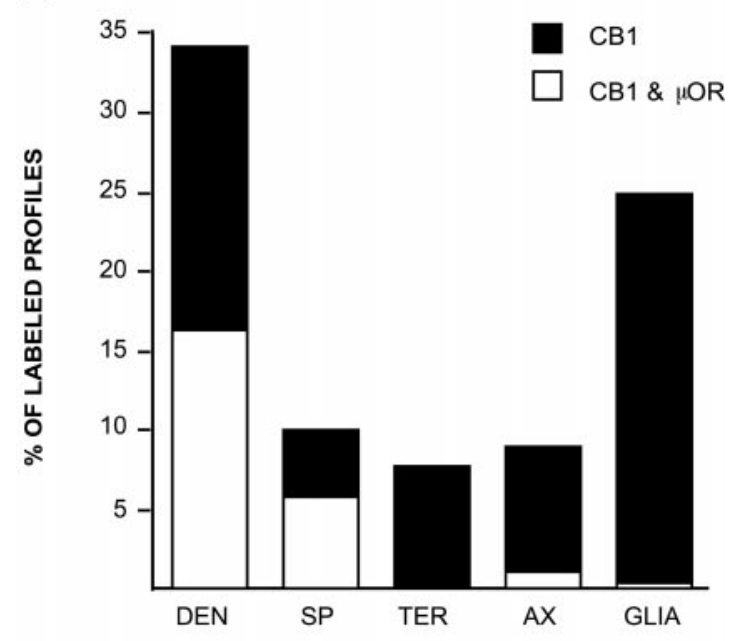

B

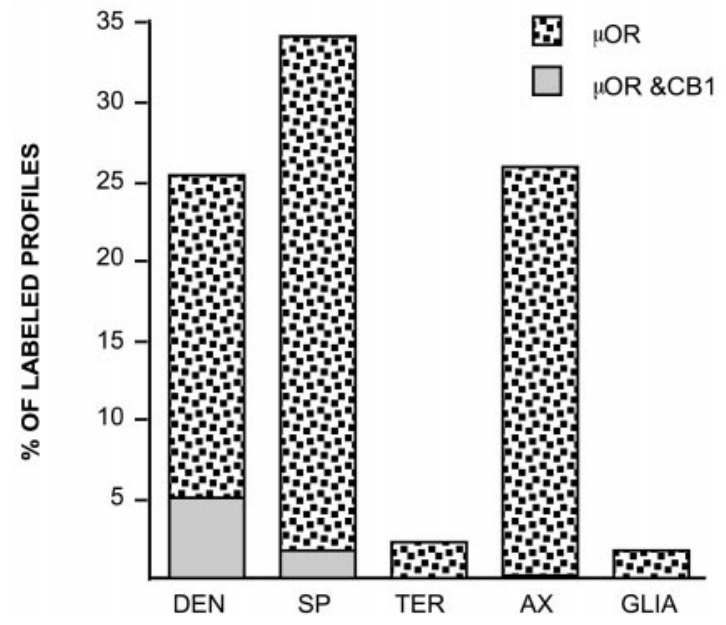

Figure 2. Bar graphs showing the proportions of different profiles containing $\mathrm{CB} 1 \mathrm{R}$ and $\mu \mathrm{OR}$ immunoreactivity in the CPN patch. These profiles include dendrites $(D E N)$, dendritic spines $(S P)$, axon terminals $(T E R)$, small axons $(A X)$, and glial processes $(G L I A)$. $A$, Percentage of each type of profile that contains either CB1R or CB1R and $\mu \mathrm{OR} . B$, Percentage of each type of profile that contains either $\mu \mathrm{OR}$ or $\mu \mathrm{OR}$ and CB1R. Data were collected from nine vibratome sections through CPN patch regions of three animals, for a total analyzed surface of 8113.90 $\mu \mathrm{m}^{2}$. All sections were processed by using immunogold for CB1R and immunoperoxidase for $\mu \mathrm{OR}$.

somata (6 of 15 ) within the CPN patch contained $\mu$ OR-LI. In these somata, as well as in those without detectable CB1R, $\mu \mathrm{OR}-\mathrm{LI}$ often was associated with segments of plasma membrane and/or with saccules of the SER. Somata containing CB1R and/or $\mu \mathrm{OR}$ received sparse synaptic input, all from unlabeled terminals. These synapses showed similar percentages of symmetric and asymmetric junctions. Of the total synapses detected on immunoreactive profiles, the synaptic contacts that were established on singly and dually labeled somata represented only $2 \%$ (14 of 653).

Dendrites were the most abundant CB1R-labeled processes in the CPN patch (see Fig. $2 A$ ). The CB1R labeling was distributed mainly on extrasynaptic and/or perisynaptic plasma membranes in small and medium-sized dendrites (Figs. 4, 5A, $B, 6 A$ ). In larger proximal dendrites and in some smaller dendrites, CB1R-LI also was observed within the cytoplasm, where membranes of SER and mitochondria were the organelles that were labeled most commonly (Figs. 4, 5A,B). In sections that were processed for dual labeling, almost one-half of CB1R-limmunoreactive dendrites contained $\mu \mathrm{OR}$ (96 of 201, 48\%; see Fig. $2 A$ ). Of the total labeled dendrites within the CPN patch, however, CB1R and dually labeled dendrites represented 18 and 16\% (105 of 584; 96 of 584), respectively. The remaining dendrites contained only $\mu \mathrm{OR}-\mathrm{LI}$ (383 of 584, 66\%). Similarly, dually labeled dendrites represented only $20 \%$ (96 of 479) of all $\mu \mathrm{OR}$-containing dendrites (see Fig. $2 B$ ). In dually labeled dendrites $\mathrm{CB} 1 \mathrm{R}$ and $\mu \mathrm{OR}$ showed mainly nonoverlapping distributions (see Figs. 2, 6A), although both receptors were associated mainly with nonsynaptic plasma membrane (see Fig. 6A). All single and dually labeled dendrites received synaptic contacts primarily from unlabeled axon terminals (112 of 119, 94.12\%; Figs. 5, 6). These included similar proportions of symmetric and asymmetric junctions.

Within the CPN patch, dendritic spines containing only CB1R represented $4 \%$ (24 of 588) of all CB1R-immunoreactive profiles, whereas $6 \%$ (35 of 588) of these profiles contained both CB1R and $\mu \mathrm{OR}$ (see Fig. $2 A$ ). Consistent with the small number of CB1R- and CB1R/ $\mu$ OR-containing spines, only $7 \%$ (48 of 653) of the synaptic inputs to labeled profiles were on these spines. Over $90 \%$ of the labeled spines received asymmetric synapses from unlabeled terminals (Figs. 5B, $C, 6 B, C$ ). In dendritic spines CB1R immunoreactivity was distributed along the plasma membrane of both head and neck regions and occasionally near the spinous apparatus in the spine necks (Figs. 5B, $C, 6 B, C$ ). Immunogold particles for CB1R also were localized to synaptic and perisynaptic portions of the plasma membrane (see Figs. 4, 6B,C).

In contrast with CB1R, $\mu$ OR-LI within the CPN patch was most prevalent in dendritic spines (see Fig. $2 B$ ), only $5 \%$ (35 of 642) of which contained CB1R (see Fig. $2 B$ ). $\mu$ OR labeling often was detected along nonsynaptic portions of the plasma membrane of spine heads and necks but also was seen in postsynaptic junctions and distributed more diffusely within the cytoplasm within dendritic spines (Fig. $6 B, C$ ). CB1R and $\mu \mathrm{OR}$ immunoreactivities rarely appeared to have overlapping distributions (Fig. $6 B, C)$. Consistent with the large number of $\mu$ OR-labeled dendritic spines, they received $72 \%$ (472 of 653) of the total synaptic input to labeled profiles within the CPN patch. These contacts were mainly asymmetric synapses (466 of 472, 99\%; Fig. $6 B, C$ ) formed by unlabeled axon terminals.

\section{Axonal CB1R distribution and relation with $\mu \mathrm{OR}$}

CB1R-LI was present in small axons and axon terminals (see Fig. 2). The CB1R-labeled terminals contained numerous SSVs and tubulovesicles as well as an occasional mitochondrion (Fig. 7A,B). The peroxidase reaction product often was associated discretely with membranes of these cytoplasmic organelles, but in some cases the reaction product also was localized intensely to presynaptic plasma membrane. Small unmyelinated axons and axon terminals comprised $\sim 17 \%$ (99 of 588) of CB1R-labeled profiles (see Fig. 2A). Within the axon terminals CB1R immunogold particles were distributed occasionally on perisynaptic portions of the plasma membrane (Fig. $7 D$ ). Of these profiles only $4 \%$ (2 of 46 ) of the small axons and $13 \%$ (7 of 53) of the axon terminals also contained $\mu \mathrm{OR}$ (see Fig. $2 A$ ). In contrast, $\mu \mathrm{OR}$ receptors were present in many small axons (489 of 1882) but in relatively few terminals (46 of 1882), representing $28 \%$ of $\mu$ OR-labeled profiles (see Figs. $2 B, 7 E$ ). The percentages of $\mu$ OR-labeled 


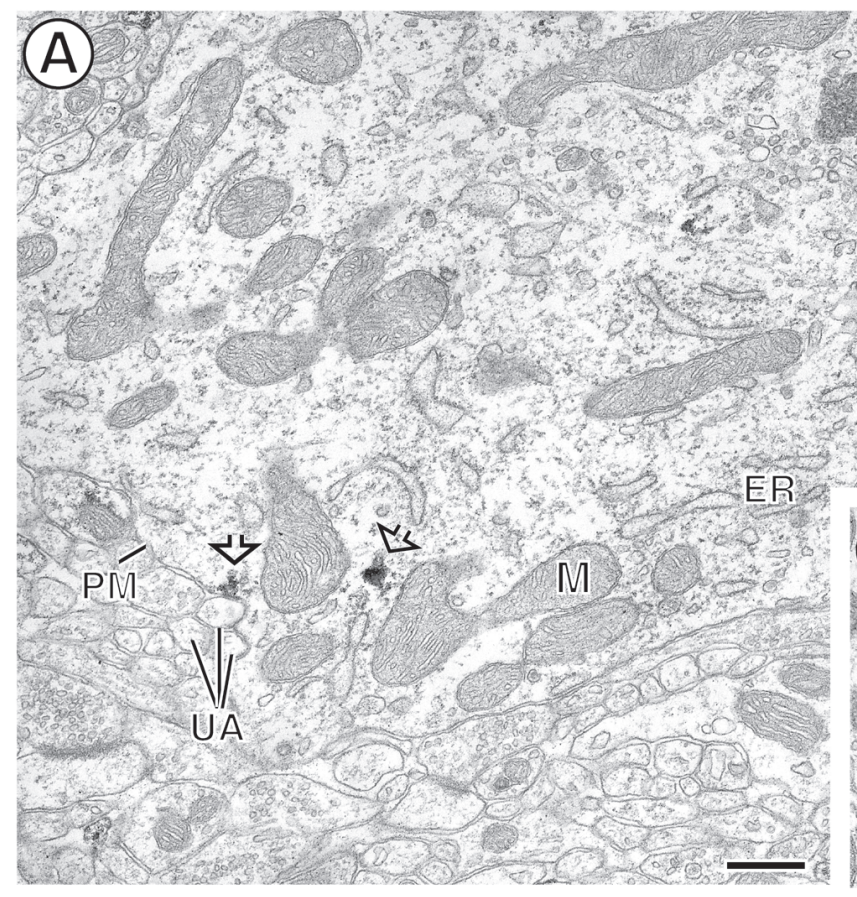

Cytoplasm

$\therefore$ Membrane

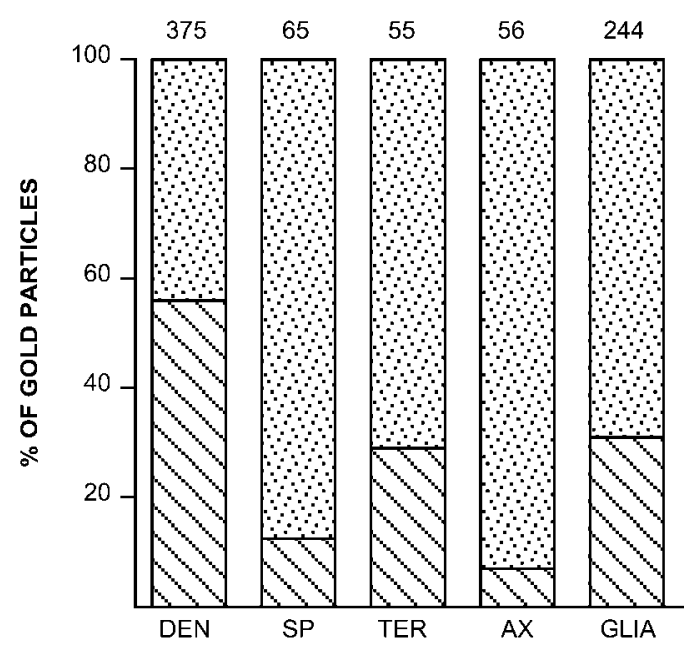

Figure 4. Bar graph showing the percentage of cytoplasmic versus plasmalemmal distribution of immunogold silver particles for CB1R in neuronal [dendrites $(D E N)$, dendritic spines $(S P)$, axon terminals $(T E R)$, small axons $(A X)]$ and glial $(G L I A)$ processes in the CPN patch. Data were collected from nine vibratome sections of three animals, for a total analyzed surface of $8113.90 \mu \mathrm{m}^{2}$.

axons and axon terminals also displaying CB1R immunoreactivity were less than the $5 \%$ (see Fig. $2 B$ ).

Within the CPN patch, axon terminals containing CB1R often were without recognizable membrane specializations but sometimes formed symmetric (5 of 24, 21\%; Fig. $7 E$ ) or more commonly asymmetric (19 of $24,79 \%$; Fig. $7 A, C, D)$ junctions. Of the total synaptic contacts that were established by labeled axon terminals, $62 \%$ (24 of 39) were formed by CB1R-labeled terminals within in the CPN patch, and only two of these also con-
Figure 3. Electron micrographs from the CPN showing immunoperoxidase localization of $\mathrm{CB} 1 \mathrm{R}$ within neuronal perikarya. $A$, Peroxidase reaction product (open arrows) on Golgi lamellae $(G)$ close to the nucleus $(\mathrm{Nu})$ and on a segment of the plasma membrane $(P M)$ apposed to small unmyelinated axons $(U A)$. Saccules of presumed smooth endoplasmic reticulum near a mitochondrion $(M)$ also show peroxidase reaction product, whereas the rough endoplasmic reticulum $(E R)$ is without immunoreactivity. $B$, Immunoperoxidase labeling within an endosome-like organelle $(E N D)$. The END is located in a portion of the cytoplasm near a contact from an unlabeled terminal (UT). $M$, Mitochondrion, $N u$, nucleus. Scale bars, $0.4 \mu \mathrm{m}$.

tained $\mu \mathrm{OR}$. The remaining $38 \%$ (15 of 39 ) were formed by $\mu$ OR-labeled terminals, and most of these were asymmetric axospinous and axodendritic synapses with or without recognizable perforations (12 of 15, 80\%). Dendrites that received input from CB1R-containing terminals were unlabeled or also contained $\mathrm{CB} 1 \mathrm{R}$ and/or $\mu \mathrm{OR}$. Dendritic spines targeted by CB1R-labeled terminals were unlabeled or $\mu \mathrm{OR}$-immunoreactive.

\section{Glial CB1R distribution and relation with $\mu \mathrm{OR}$}

CB1R labeling was seen prominently in glial cell bodies as well as in many filamentous glial processes throughout the CPN (see Figs. 1, 8). The CB1R-labeled glial profiles in patches represented $25 \%$ (147 of 588) of the CB1R-immunoreactive profiles (see Fig. $2 A$ ). Peroxidase reaction product for $\mathrm{CB} 1 \mathrm{R}$ was distributed throughout the cytoplasm and along the plasma membrane of the glial processes (Fig. 8A,C). Immunogold particles also were seen in the cytoplasm and along the plasma membrane (see Figs. 4, $8 B$ ). The CB1R-labeled glial processes were often perivascular and apposed the basal membrane of endothelial cells lining the blood vessels (see Figs. $1 A, 8 A, B$ ). Other labeled glial processes within the neuropil were perisynaptic (Fig. 8). These apposed presynaptic and/or postsynaptic profiles at asymmetric axospinous synapses (Fig. 8A,C). Only three of 147 (2\%) of the CB1Rlabeled glial profiles contained $\mu \mathrm{OR}$ immunoreactivity (see Fig. $2 A$ ). Exclusively $\mu$ OR-labeled glial profiles also were seen rarely (see Fig. 2B).

\section{DISCUSSION}

Our results demonstrate that $\mathrm{CB} 1 \mathrm{R}$ has a discrete cytoplasmic location within somata and dendrites in the CPN, where the regional and cellular distributions are mainly distinct from $\mu \mathrm{OR}$. Within $\mu \mathrm{OR}$-enriched patches, however, CB1R and $\mu \mathrm{OR}$ are also present in some of the same spiny neurons, suggesting that dual modulation of the output from these mainly GABAergic projection neurons may, in part, account for the motor inhibition produced by both cannabinoids and opioids. In addition, we also establish that many mainly excitatory-type axon terminals and associated glial processes, as well as perivascular astrocytes, ex- 
Figure 5. Dendrites and dendritic spines containing immunoperoxidase reaction product ( $A, B$, open arrows) and immunogold $(C$, arrows $)$ labeling for CB1R. A, Peroxidase reaction product on the plasma membrane and aggregated within the adjacent cytoplasm, separating the plasma membrane from a nearby mitochondrion $(M)$. The labeling is near an asymmetric synapse (black curved arrow) established by an unlabeled terminal (UT1). The postsynaptic specialization in this dendrite also appears more electron dense than the one established (gray curved arrow) by a nearby unlabeled terminal (UT2) with an unlabeled spine $(U S p)$. The labeled dendritic plasma membrane is apposed by an unlabeled glial process (asterisk) located near small unmyelinated axons $(U A) . B$, Peroxidase reaction product associated with smooth endoplasmic reticulum (SER) and with the plasma membrane at the base of a dendritic spine. The reaction product also is distributed throughout the spine neck and head, which receives an asymmetric synapse (curved arrow) from an unlabeled terminal (UT1). The CB1R-labeled dendrite $(C B 1 R D)$ is apposed by another unlabeled terminal (UT2) and by an unlabeled dendrite $(U D)$. $C$, Immunogold labeling on the plasma membrane close to the spinous apparatus $(S p A p)$ in a dendritic spine neck. The labeled spine $(C B 1 R S p)$ receives an asymmetric synapse (curved arrow) from an unlabeled terminal $(U T)$. Scale bars: $A, B, 0.25$ $\mu \mathrm{m} ; C, 0.3 \mu \mathrm{m}$.
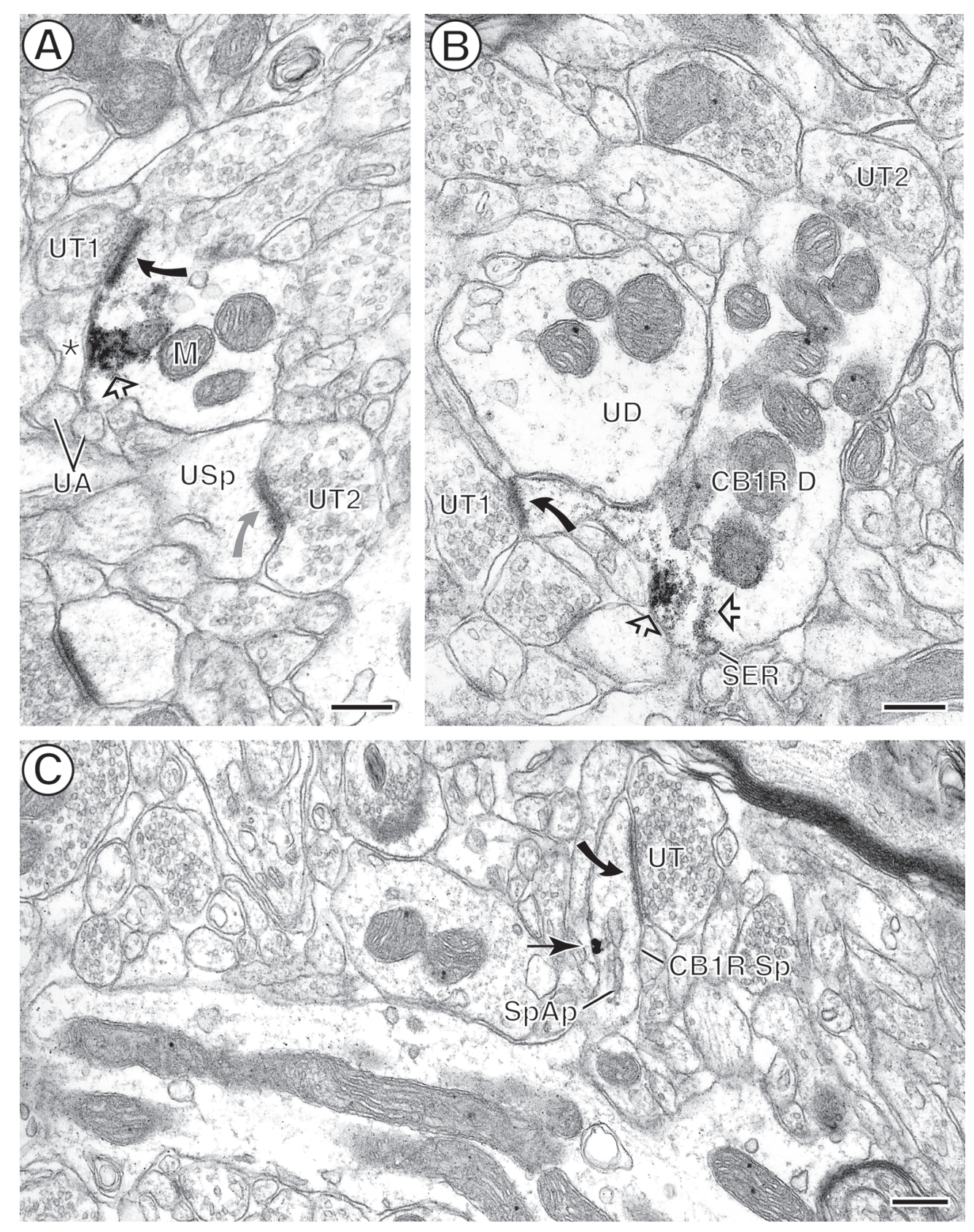

press CB1R. Together, these results suggest diverse functional sites for striatal activation of CB1R that may affect directly the postsynaptic excitability of spiny neurons and presynaptic availability of amino acid transmitters in the CPN. They also indicate that glial CB1R may play a novel role in coupling neuronal activity with cerebral blood flow and/or metabolism.

\section{Colocalization of CB1R and $\mu \mathrm{OR}$ in patch neurons}

The observed colocalization of CB1R and $\mu \mathrm{OR}$ in somata and dendrites of several spiny neurons in $\mathrm{CPN}$ patches suggests that at least some of the common physiological actions produced by cannabinoids and opioids reflect dual targeting to single cells. This is consistent with the fact that both the $\mu \mathrm{OR}$ and CB1R are found in striatal GABAergic neurons (Svingos et al., 1997; Tsou et al., 1998; Wang et al., 1999; Hohmann and Herkenham, 2000). In addition, the association of $\mathrm{CB} 1 \mathrm{R}$ and $\mu \mathrm{OR}$ with similar cytoplasmic organelles in single neurons in the present study suggests potential coupling to similar second messenger systems. This hypothesis is supported by the fact that both receptors are known to be coupled to $\mathrm{G}_{\mathrm{i}} / \mathrm{G}_{\mathrm{o}}$ GTP-binding proteins and inhibit adenylyl cyclase activity, block voltage-dependent calcium channels, and activate potassium channels (Childers, 1991; Howlett, 1995; Shapira et al., 1998). Thus, in neurons containing both $\mathrm{CB} 1 \mathrm{R}$ and $\mu \mathrm{OR}$, there may be reciprocal competition for the same pool of $\mathrm{G}_{\mathrm{i}}$-proteins (Corchero et al., 1999). Based on the presently observed distribution, it is likely, however, that the output from spiny neurons within patch regions is affected more prominently by $\mu \mathrm{OR}$ activation, whereas cannabinoids also affect the inhibitory output of matrix neurons.

\section{Cellular and subcellular targeting of CB1R}

The present localization of CB1R within somata and dendrites of spiny neurons throughout the CPN confirms and extends light 

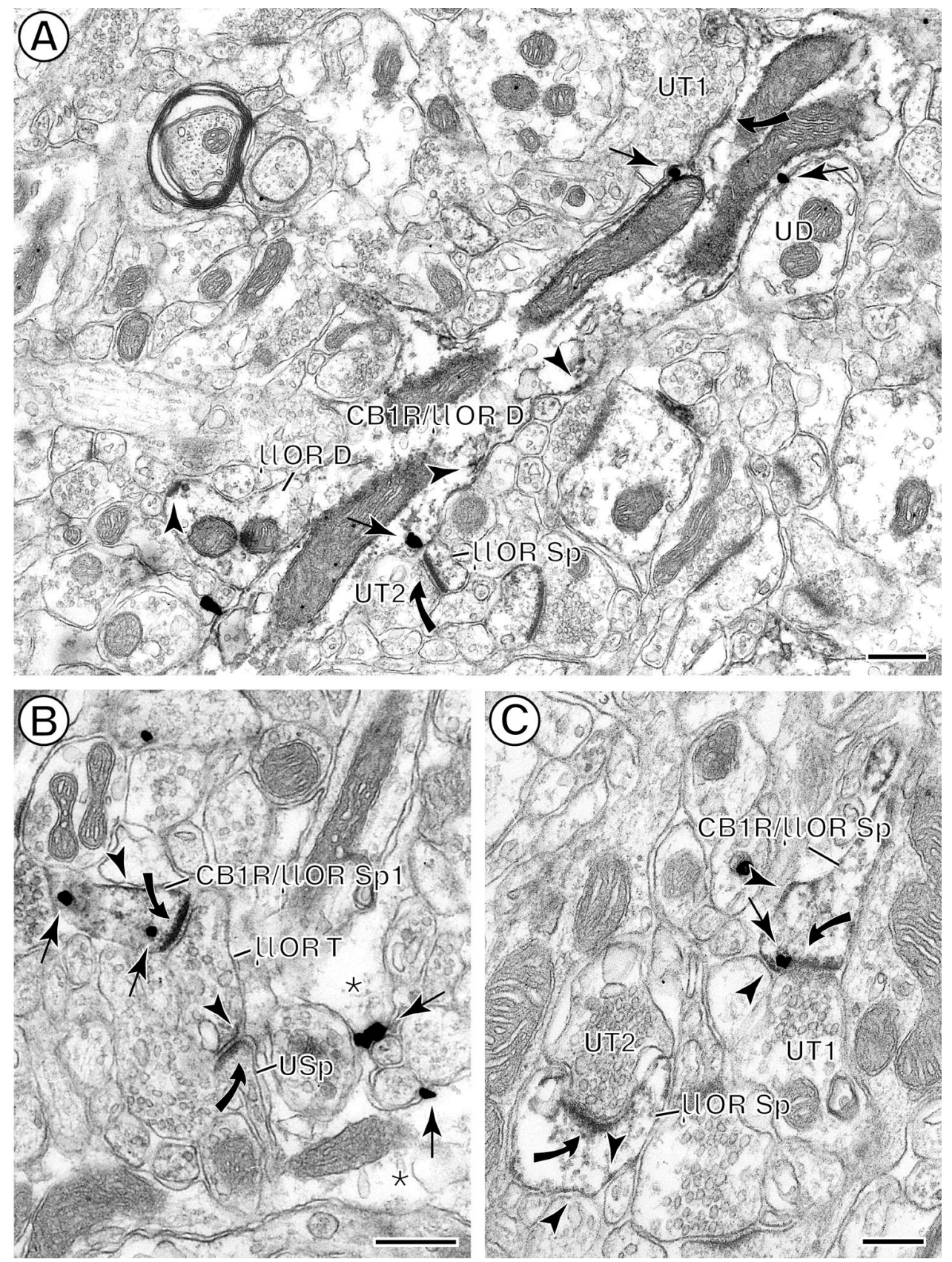

Figure 6. Colocalization of immunoperoxidase reaction product for $\mu \mathrm{OR}$ (arrowheads) and immunogold particles for CB1R (arrows) in spiny dendrites in the CPN patch. $A$, A longitudinal section of a dually labeled dendrite $(C B 1 R / \mu O R D)$ containing $\mathrm{CB} 1 \mathrm{R}$ and $\mu \mathrm{OR}$. Both peroxidase labeling and gold labeling are shown prominently on the plasma membrane. Diffuse $\mu$ OR-reaction product also is seen throughout the cytoplasm. CB1R/ $/ \mu$ OR D is contacted by two unlabeled terminals $(U T 1, U T 2)$, but only UT1 forms an asymmetric synapse (curved arrow) with the dually labeled dendrite. UT2 forms an asymmetric synapse (curved arrow) with a $\mu \mathrm{OR}$ labeled spine ( $\mu O R S p)$. This dendrite also is apposed by a $\mu$ OR-labeled dendrite $(\mu O R D)$ and an unlabeled dendrite $(U D)$. $B$, Dually labeled dendritic spine $(C B 1 R /$ $\mu O R S p$ ). Cytoplasmic CB1R immunogold labeling and $\mu \mathrm{OR}$ peroxidase labeling are seen on the plasma membrane. The peroxidase $\mu \mathrm{OR}$ also is distributed more diffusely throughout the spine. The spine receives an asymmetric synapse (curved arrow) from a $\mu \mathrm{OR}$-labeled terminal ( $\mu \mathrm{OR}$ $T$ ). $C$, Perisynaptic CB1R and $\mu \mathrm{OR}$ distributions near an asymmetric axospinous synapse from an unlabeled terminal (UT1). The peroxidase reaction product for $\mu \mathrm{OR}$ also is expressed, however, on other portions of the plasma membrane and cytoplasm in this spine as well as in a second spine $(\mu O R S p)$. This spine receives an asymmetric synapse from an unlabeled terminal (UT2). Scale bars: $A, B, 0.4 \mu \mathrm{m} ; C$, $0.25 \mu \mathrm{m}$. microscopic studies showing that CB1R mRNA and protein are distributed homogeneously in this brain region (Matsuda et al., 1990; Herkenham et al., 1991a-c; Mailleux and Vanderhaegen, 1992; Pettit et al., 1998; Tsou et al., 1998; Hohmann and Herkenham, 2000). CB1R somatodendritic localization differs, however, from the recent light microscopic study showing CB1R labeling only in presumed axonal processes within the CPN (Egertová and Elphick, 2000). Most likely these differences are mainly methodological, because there were major differences in antisera and tissue preparation in our study as compared with Egertová and Elphick (2000).

The somatic and dendritic distribution of CB1R-LI near the plasma membrane and in association with the SER and Golgi apparatus suggests that these are sites for activation and intracellular trafficking of $\mathrm{CB} 1 \mathrm{R}$ in the $\mathrm{CPN}$ and are similar to those reported in other brain regions (Katona et al., 1999). Our detection of CB1R within somatic multivesicular bodies and/or endosomes that are involved in internalization and recycling of receptor proteins also is in agreement with the recent description of rapid $\mathrm{CB} 1 \mathrm{R}$ internalization after administration of efficacious cannabinoid agonists such as WIN 55212-2 (Hsieh et al., 1999). These endosome-like organelles may be involved in trafficking CB1R not only to local dendrites but also to axon terminals in the globus pallidus, where CB1R binding sites are abundant and functionally active (Herkenham et al., 1991b,c; Sañudo-Peña and Walker, 1998; Tsou et al., 1998; SañudoPeña et al., 1999).

The presence of CB1R in GABAergic striatal neurons is supported by our detection of CB1R on plasma membranes of some inhibitory-type terminals that most likely originate as local collaterals of spiny projection neurons and/or interneurons (Hohmann and Herkenham, 2000). We observed nuclei typical of each 
Figure 7. Localization of $\mathrm{CB} 1 \mathrm{R}$ in axon terminals, one of which contains $\mu \mathrm{OR}$. $A$, Immunoperoxidase CB1R labeling (open arrow) on the plasma membrane of an axon terminal $(C B 1 R T)$. The reaction product also is distributed diffusely on membranes of nearby small synaptic vesicles (SSVs). The CB1R-labeled terminal establishes an asymmetric synapse (curved arrow) with a CB1R-labeled dendritic spine $(C B 1 R S p)$. $B$, Cytoplasmic $\mathrm{CB} 1 \mathrm{R}$ reaction product (open arrow) associated with tubulovesicles near a mitochondrion $(M)$ in an axon terminal $(C B 1 R T)$ without any recognizable synaptic specialization. The terminal also contains many small synaptic vesicles (SSVs). C, Plasmalemmal (open arrows) and cytoplasmic CB1R peroxidase labeling within an axon terminal (CB1R T) forming an asymmetric synapse (curved arrow) with an unlabeled spine $(U S p)$. One plasmalemmal aggregate of reaction product is seen on the presynaptic membrane of the asymmetric junction and is apposed by an unlabeled terminal $(U T)$. The spine contains a spine apparatus $(S p A p)$ in the neck region. $D$, Immunogold CB1R (arrow) labeling on the presynaptic plasma membrane of a terminal $(C B 1 R T)$ forming asymmetric synapses (curved arrows) with two unlabeled dendritic spines (USp1, USp2). The location of the presynaptic gold particle is almost identical to that of the presynaptic plasmalemmal peroxidase reaction in $C$. The terminal and the spine are apposed by an unlabeled terminal (UT). E, Diffuse cytoplasmic immunoperoxidase reaction product for $\mu \mathrm{OR}$ is seen in an axon terminal $(C B 1 R / \mu O R T)$ that contains gold particles (arrows) for CB1R. The terminal is apposed to an unlabeled dendrite (UD1) and establishes a synapse (solid thick arrow) with an unlabeled small dendrite (UD2). Scale bars: $A, B, 0.2 \mu \mathrm{m} ; C, D, 0.25$ $\mu \mathrm{m} ; E, 0.4 \mu \mathrm{m}$.
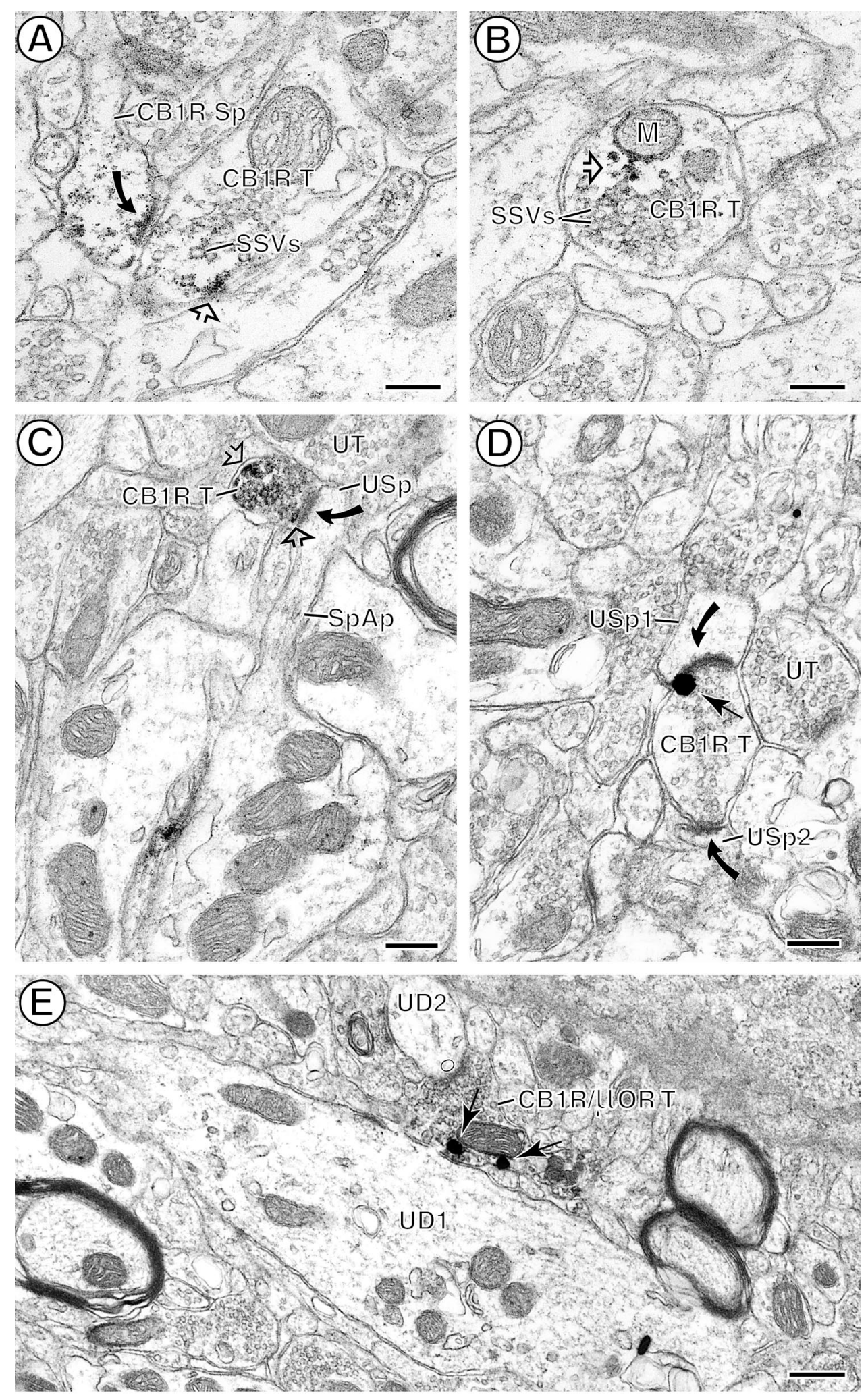

cell type (DiFiglia et al., 1980) in somata containing CB1R. Moreover, all spiny neurons and many interneurons contain GABA (Smith et al., 1998). Thus, activation of presynaptic CB1R may reduce GABA release and subsequently reduce inhibitory postsynaptic currents in the CPN (Szabo et al., 1998). The CB1Rlabeled terminals forming symmetric synapses also may contain either acetylcholine or dopamine, because these neurotransmitters are present in morphologically similar terminals (Pickel et al., 1981; DiFiglia, 1987; Contant et al., 1996). The presence of acetylcholine seems unlikely, however, because cholinergic striatal interneurons do not express CB1R mRNA (Hohmann and Herkenham, 2000). 


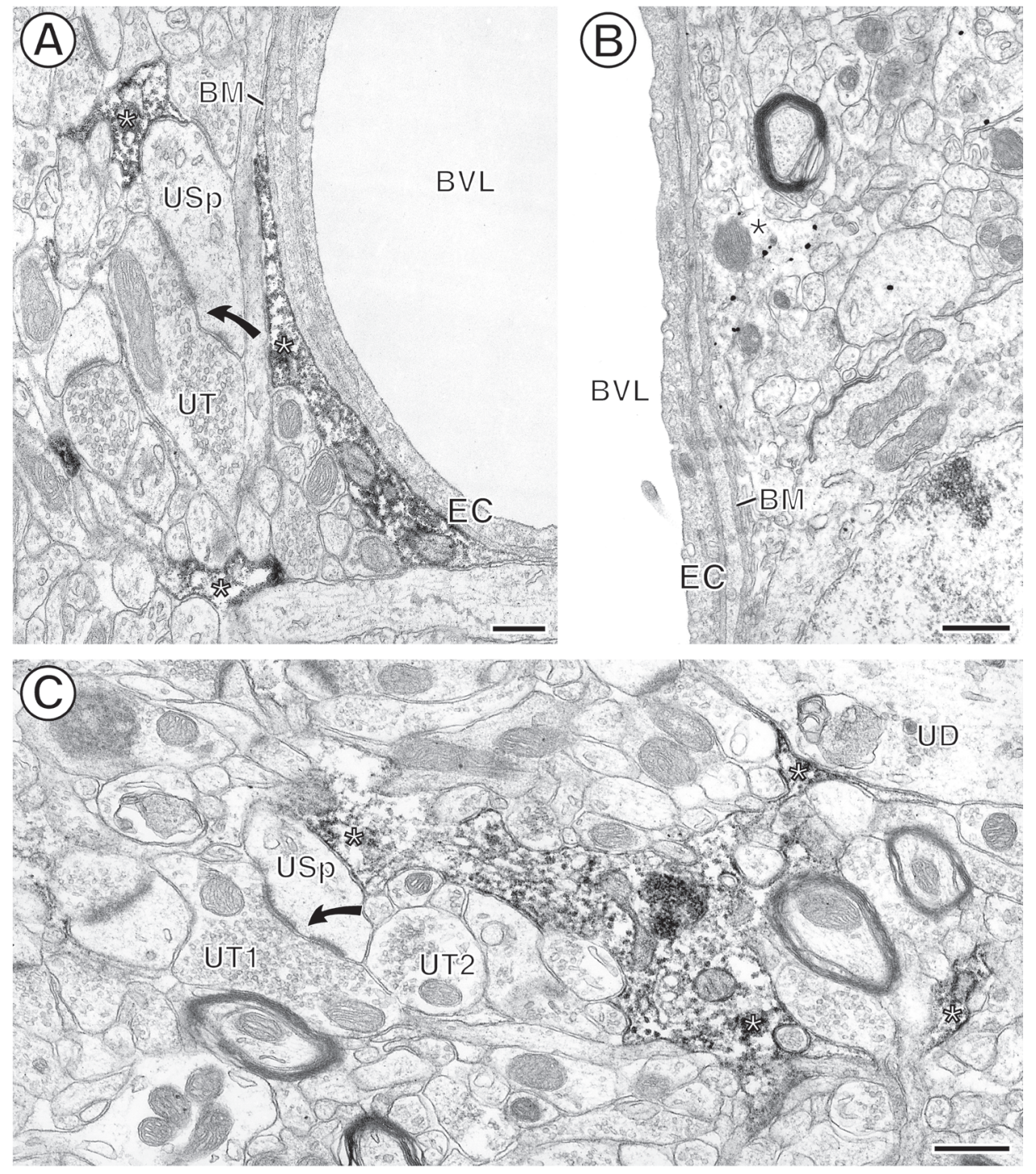

Figure 8. Immunoperoxidase and immunogold CB1R labeling of glial processes (asterisks). A, Peroxidase reaction product within the cytoplasm of glial processes (asterisks) apposed to the basal membrane $(B M)$ of endothelial cells $(E C)$ lining the blood vessel lumen $(B V L)$. Another CB1Rlabeled glial process is apposed to an unlabeled spine (USp) that receives a perforated asymmetric synapse (curved arrow) from an unlabeled terminal (UT). $B$, Immunogold-labeled perivascular glial process. Abbreviations are the same as in $A$. $C$, Peroxidase labeling for CB1R within the cytoplasm and along discrete segments of the plasma membrane of a perisynaptic glial profile. The glial process apposes an unlabeled dendrite $(U D)$ and an unlabeled spine (USp). The spine receives a perforated asymmetric synapse (curved arrow) from an unlabeled terminal (UT1) and is apposed to another unlabeled terminal (UT2). Scale bars: $A, 0.3$ $\mu \mathrm{m} ; B, C, 0.5 \mu \mathrm{m}$.

\section{CB1R localization in excitatory terminals}

Our observed localization of CB1R-LI to presynaptic plasma membranes of excitatory-type terminals in the CPN is in agreement with the reported distribution of CB1R immunolabeling in cortical pyramidal neurons that are major sources of excitatory inputs to striatal spine heads (Tsou et al., 1998; Ong and Mackie, 1999). These results suggest that the CB1R is transported anterogradely from somatic sites of synthesis in cortex to excitatory axon terminals in the CPN. Thus, the activation of the CB1R on corticostriatal terminals may modulate the postsynaptic excitability of spiny neurons in the $\mathrm{CPN}$ via changes in presynaptic release of glutamate. Inhibition of glutamate release by CB1R activation would result in a reduction in excitatory postsynaptic currents in the CPN, as reported in several brain regions (Shen et al., 1996; Lévénes et al., 1998; Auclair et al., 2000; Kim and Thayer, 2000; Szabo et al., 2000; Takahashi and Linden, 2000). Activation of CB1R may decrease presynaptic glutamate release via the inhibition of $\mathrm{N}$ - and P-type $\mathrm{Ca}^{2+}$ channels and/or changes in the activity of $\mathrm{K}^{+}$channels (Mackie et al., 1993, 1995; Wheeler et al., 1994; Henry and Chavkin, 1995; Shen et al., 1996; Takahashi and Linden, 2000).

\section{CB1R in perisynaptic and perivascular glia}

Our results provide direct in vivo evidence for selective CB1R distribution in perisynaptic and perivascular glial processes in the CNS. The localization is consistent with the known presence of CB1R mRNA and protein in astrocytic and glioma/astrocytoma cell cultures (Sánchez et al., 1998a,b; Guzmán and Sánchez, 1999; Bouaboula et al., 2000). In addition, astrocytes in culture have been shown to bind and take up the CB1R endogenous ligand, anandamide (Di Marzo et al., 1994). Others have suggested, however, that glial cannabinoid receptors are distinct from CB1R (Sagan et al., 1999). This discrepancy might reflect the fact that the CB1R antiserum used in the present study recognizes the related glial receptor protein. This seems unlikely, however, because our antiserum has been shown to be highly selective for CB1R (Twitchell et al., 1997; Tsou et al., 1998). In contrast with our results in the CPN, an ultrastructural study that used this antiserum in the hippocampal formation failed to detect glial labeling (Katona et al., 1999). This may reflect variability in CB1R distribution in glial cells that parallels regional differences in neuronal activity, as suggested by known regional differences in the involvement of CB1R in glial gap junction conductances 
(Venance et al., 1995). We cannot, however, exclude the possibility that the regional differences in glial CB1R labeling are attributed to differences in methodology, because fixation conditions and labeling protocols differed between our study and that of Katona et al. (1999).

The selective perisynaptic distribution of CB1R in glial processes near excitatory-type axospinous synapses suggests that glial CB1R is involved in glutamatergic transmission. Perisynaptic astrocytes express the glutamate transporter and also contain the enzymes required for conversion of glutamate to glutamine, which is required for glutamate synthesis (Sonnewald et al., 1997; Hertz et al., 1999). Thus, astrocytic CB1R in the CPN may play a role similar to that previously suggested for glial metabotropic glutamate receptors in other brain regions, mediating specific neuron-glia interactions (Mineff and Valtschanoff, 1999). The endogenous cannabinoids may, in fact, be derived from glutamatergic corticostriatal neurons (Cadas et al., 1996), accounting for the presence of CB1R and metabotropic glutamate receptors on glial processes near excitatory-type synapses. Furthermore, glutamate evokes $\mathrm{Ca}^{2+}$ waves in adjacent astrocytes, triggering a response in neighbor neurons that may be modulated and/or blocked by cannabinoids (Cornell-Bell et al., 1990; Charles et al., 1992; Charles, 1994; Nedergaard, 1994; Venance et al., 1995).

In addition to ramifications near excitatory axospinous synapses, CB1R-labeled astrocytic processes were associated prominently with the basal membranes of blood vessels. This distribution suggests the involvement of CB1R in coupling neuronal activity with blood flow and/or metabolism (Alkayed et al., 1997; Guzmán and Sánchez, 1999). In cultured astrocytes the production of glutamine from glutamate via the tricarboxylic cycle generates adenosine triphosphate (ATP; Hertz et al., 1999), and ATP induces the release of arachidonic acid via $\mathrm{G}_{\mathrm{i}}$-protein-coupled purinergic receptors (Chen and Chen, 1998). Furthermore, cannabinoids and arachidonic acid are potent vasodilators (Hillard, 2000). Together, these observations suggest a potentially novel role for CB1R in glutamatergic transmission and concomitant changes in the cerebral circulation in response to neuronal activity. These actions may be interrelated with astrocytic regulation of energy metabolism (Lavado et al., 1997; Pellerin et al., 1997; Guzmán and Sánchez, 1999).

\section{REFERENCES}

Alkayed NJ, Birks EK, Narayanan J, Petrie KA, Kohler-Cabot AE, Harder DR (1997) Role of P-450 arachidonic acid epoxygenase in the response of cerebral blood flow to glutamate in rats. Stroke 28:1066-1072.

Arvidsson U, Riedl M, Chakrabarti S, Lee J, Nakano AH, Dado RJ, Loh HH, Law P, Wessendorf MW, Elde R (1995) Distribution and targeting of a $\mu$-opioid receptor (MOR1) in brain and spinal cord. J Neurosci 15:3328-3341.

Auclair N, Otani S, Soubrié P, Crépel F (2000) Cannabinoids modulate synaptic strength and plasticity at glutamatergic synapses of rat prefrontal cortex pyramidal neurons. J Neurophysiol 83:3287-3293.

Bouaboula M, Bourrié B, Rinaldi-Carmona M, Shire D, Le Fur G, Casellas P (2000) Stimulation of cannabinoid receptor CB1 induces krox-24 expression in human astrocytoma cells. J Biol Chem 270:13973-13980.

Boudin H, Pelaprat D, Rostene W, Pickel VM, Beaudet A (1998) Correlative ultrastructural distribution of neurotensin receptor proteins and binding sites in the rat substantia nigra. J Neurosci 18:8473-8484.

Cadas H, Gaillet S, Beltramo M, Venance L, Piomelli D (1996) Biosynthesis of an endogenous cannabinoid precursor in neurons and its control by calcium and cAMP. J Neurosci 16:3934-3942.

Chan J, Aoki C, Pickel VM (1990) Optimization of differential immunogold-silver and peroxidase labeling with maintenance of ultrastructure in brain sections before plastic embedding. J Neurosci Methods 33:113-127.

Charles AC (1994) Glia-neuron intercellular calcium signaling. Dev Neurosci 16:196-206.
Charles AC, Naus CC, Zhu D, Kidder GM, Dirksen ER, Sanderson MJ (1992) Intercellular calcium signaling via gap junctions in glioma cells. J Cell Biol 118:195-201.

Chen WC, Chen CC (1998) ATP-induced arachidonic acid release in cultured astrocytes is mediated by $\mathrm{G}_{\mathrm{i}}$-protein-coupled P2Y1 and P2Y2. Glia 22:360-370.

Childers SR (1991) Opioid receptor-coupled second messenger system. Life Sci 48:1991-1203.

Compton DR, Aceto MD, Lowe J, Martin BR (1996) In vivo characterization of a specific cannabinoid receptor antagonist (SR141716A): inhibition of $\Delta^{9}$-tetrahydrocannabinol-induced responses and apparent agonist activity. J Pharmacol Exp Ther 277:586-594.

Contant C, Umbriaco D, Garcia S, Watkins KC, Descarries L (1996) Ultrastructural characterization of the acetylcholine innervation in adult rat neostriatum. Neuroscience 71:937-947.

Corchero J, Romero J, Berrendero F, Fernández-Ruiz JJ, Ramos JA, Fuentes JA, Manzanares J (1999) Time-dependent differences of repeated administration of Delta ${ }^{9}$-tetrahydrocannabinol in proenkephalin and cannabinoid receptor gene expression and G-protein activation by $\mu$-opioid and CB1-cannabinoid receptors in the caudate putamen. Mol Brain Res 67:148-157.

Cornell-Bell AH, Finkbeiner SM, Cooper MS, Smith SJ (1990) Glutamate induces calcium waves in cultured astrocytes: long-range glial signaling. Science 247:470-473.

Devane WA, Dysarz 3rd FA, Johnson MR, Melvin LS, Howlett AC (1988) Determination and characterization of a cannabinoid receptor in rat brain. Mol Pharmacol 34:605-613.

Devane WA, Hanus L, Breuer A, Pertwee RG, Stevenson LA, Griffin G, Gibson D, Mandelbaum A, Etinger A, Mechoulam R (1992) Isolation and structure of a brain constituent that binds to the cannabinoid receptor. Science 258:1946-1949.

DiFiglia M (1987) Synaptic organization of cholinergic neurons in the monkey neostriatum. J Comp Neurol 255:245-258.

DiFiglia M, Pasik T, Pasik P (1980) Ultrastructure of Golgi-impregnated and gold-toned spiny and aspiny neurons in the monkey neostriatum. J Neurocytol 9:471-492.

Di Marzo V, Fontana A, Cadas H, Schinelli S, Cimino G, Schwartz JC, Piomelli D (1994) Formation and inactivation of endogenous cannabinoid anandamide in central neurons. Nature 372:686-691.

Donoghue JP, Herkenham M (1986) Neostriatal projections from individual cortical fields conform to histochemically distinct striatal compartments in the rat. Brain Res 36:397-403.

Egertová M, Elphick MR (2000) Localisation of cannabinoid receptors in the rat brain using antibodies to the intracellular C-terminal tail of $\mathrm{CB}_{1}$. J Comp Neurol 422:159-171.

Garzón M, Vaughan RA, Uhl GR, Kuhar MJ, Pickel VM (1999) Cholinergic axon terminals in the ventral tegmental area target a subpopulation of neurons expressing low levels of the dopamine transporter. J Comp Neurol 410:197-210.

Gerfen CR (1984) The neostriatal mosaic: compartmentalization of corticostriatal input and striatonigral output systems. Nature 311:461-464.

Greenough WT, West RV, De Voogd TJ (1978) Subsynaptic plate perforations: changes with age and experience in the rat. Science 202: 1096-1098.

Guzmán M, Sánchez C (1999) Effects of cannabinoids on energy metabolism. Life Sci 65:657-664.

Henry DJ, Chavkin C (1995) Activation of inwardly rectifying potassium channels (GIRK1) by coexpressed rat brain cannabinoid receptors in Xenopus oocytes. Neurosci Lett 186:91-94.

Herkenham M, Pert CB (1982) Light microscopic localization of brain opiate receptors: a general autoradiographic method which preserves tissue quality. J Neurosci 2:1129-1149.

Herkenham M, Lynn AB, Little MD, Johnson MR, Melvin LS, de Costa BR, Rice KC (1990) Cannabinoid receptor localization in brain. Proc Natl Acad Sci USA 87:1932-1936.

Herkenham M, Groen BGS, Lynn AB, de Costa BR, Richfield EK (1991a) Neuronal localization of cannabinoid receptors and second messengers in mutant mouse cerebellum. Brain Res 552:301-310.

Herkenham M, Lynn AB, de Costa BR, Richfield EK (1991b) Neuronal localization of cannabinoid receptors in the basal ganglia of the rat. Brain Res 547:267-274.

Herkenham M, Lynn AB, Johnson MR, Melvin LS, de Costa BR, Rice KC (1991c) Characterization and localization of cannabinoid receptors in rat brain: a quantitative in vitro autoradiographic study. J Neurosci 11:563-583.

Hertz L, Dringen R, Schousboe A, Robinson SR (1999) Astrocytes: glutamate producers for neurons. J Neurosci Res 57:417-428.

Hillard CJ (2000) Endocannabinoids and vascular function. J Pharmacol Exp Ther 294:27-32.

Hohmann AG, Herkenham M (2000) Localization of cannabinoid CB $_{1}$ receptor mRNA in neuronal subpopulations of rat striatum: a doublelabel in situ hybridization study. Synapse 37:71-80.

Howlett AC (1985) Cannabinoid inhibition of adenylate cyclase. Biochemistry of the response in neuroblastoma cell membranes. Mol Pharmacol 27:429-436. 
Howlett AC (1995) Pharmacology of cannabinoid receptors. Annu Rev Pharmacol Toxicol 35:607-634.

Howlett AC, Bidaut-Russell M, Devane WA, Melvin LS, Johnson MR, Herkenham M (1990) The cannabinoid receptor: biochemical, anatomical, and behavioral characterization. Trends Neurosci 13:420-423.

Hsieh C, Brown S, Derleth C, Mackie K (1999) Internalization and recycling of the CB1 cannabinoid receptor. J Neurochem 73:493-501.

Johnston JG, Gerfen CR, Haber SN, Van der Kooy D (1990) Mechanisms of striatal pattern formation: conservation of mammalian compartmentalization. Brain Res Dev 57:93-102.

Katona I, Sperlágh B, Sik A, Käfalvi A, Vizi ES, Mackie K, Freund TF (1999) Presynaptically located CB1 cannabinoid receptors regulate GABA release from axon terminals of specific hippocampal interneurons. J Neurosci 19:4544-4558.

Kim DJ, Thayer SA (2000) Activation of CB1 cannabinoid receptors inhibits neurotransmitter release from identified synaptic sites in rat hippocampal cultures. Brain Res 852:398-405.

Lavado E, Sánchez-Abarca LI, Tabernero A, Bolanos JP, Medina JM (1997) Oleic acid inhibits gap junction permeability and increases glucose uptake in cultured rat astrocytes. J Neurochem 69:721-728.

Leranth C, Pickel VM (1989) Electron microscopic pre-embedding double immunostaining methods. In: Tract-tracing methods, recent progress (Heimer L, Zaborsky L, eds), pp 129-172. New York: Plenum.

Lévénes C, Daniel H, Soubrié P, Crépel F (1998) Cannabinoids decrease excitatory synaptic transmission and impair long-term depression in rat cerebellar Purkinje cells. J Physiol (Lond) 510:867-879.

Little PJ, Compton DR, Johnson MR, Melvin LS, Martin BR (1988) Pharmacology and stereoselectivity of structurally novel cannabinoids in mice. J Pharmacol Exp Ther 247:1046-1051.

Mackie K, Devane WA, Hille B (1993) Anandamide, an endogenous cannabinoid, inhibits calcium currents as a partial agonist in N18 neuroblastoma cells. Mol Pharmacol 44:498-503.

Mackie K, Lai Y, Westenbroek R, Mitchell R (1995) Cannabinoids activate an inwardly rectifying potassium conductance and inhibit Q-type calcium currents in AtT20 cells transfected with rat brain cannabinoid receptor. J Neurosci 15:6552-6561.

Mailleux P, Vanderhaegen J-J (1992) Distribution of neuronal cannabinoid receptor in the adult rat brain: a comparative receptor binding radioautography and in situ hybridization histochemistry. Neuroscience 48:655-668.

Mansour A, Khachaturian H, Lewis ME, Akil H, Watson SJ (1987) Autoradiographic differentiation of $\mu, \delta$, and $\kappa$ opioid receptors in the forebrain and midbrain. J Neurosci 7:2445-2464.

Mansour A, Fox CA, Akil H, Watson SJ (1995) Opioid receptor mRNA expression in the rat CNS: anatomical and functional implications. Trends Neurosci 18:22-29.

Manzanares J, Corchero J, Romero J, Fernández-Ruiz JJ, Ramos JA, Fuentes JA (1999) Pharmacological and biochemical interactions between opioids and cannabinoids. Trends Pharmacol Sci 20:287-294.

Matsuda LA, Lolait SJ, Brownstein MJ, Young AL, Bonner TI (1990) Structure of a cannabinoid receptor and functional expression of the cloned cDNA. Nature 346:561-564.

Matsuda LA, Bonner TI, Lolait SJ (1993) Localization of cannabinoid receptor mRNA in rat brain. J Comp Neurol 327:535-550.

Mineff E, Valtschanoff J (1999) Metabotropic glutamate receptors 2 and 3 expressed by astrocytes in rat ventrobasal thalamus. Neurosci Lett 270:95-98.

Nedergaard M (1994) Direct signaling from astrocytes to neurons in cultures of mammalian brain cells. Science 263:1768-1771.

Ong W Y, Mackie K (1999) A light and electron microscopic study of the CB1 cannabinoid receptor in primate brain. Neuroscience 92:1177-1191.

Page KJ, Besret L, Jain M, Monaghan EM, Dunnet SB, Everitt BJ (2000) Effects of systemic 3-nitropropionic acid-induced lesions of the dorsal striatum on cannabinoid and $\mu$-opioid receptor binding in the basal ganglia. Exp Brain Res 130:142-150.

Paxinos G, Watson C (1986) The rat brain in stereotaxic coordinates. New York: Academic.

Pellerin L, Stolz M, Sorg O, Martin JL, Deschepper CL, Magistretti PJ (1997) Regulation of energy metabolism by neurotransmitters in astrocytes in primary culture and in an immortalized cell line. Glia 21:74-83.

Peters A, Palay SL, Webster HD (1991) The fine structure of the nervous system. New York: Oxford UP.

Pettit DA, Harrison MP, Olson JM, Spencer RF, Cabral GA (1998) Immunohistochemical localization of the neural cannabinoid receptor in rat brain. J Neurosci Res 51:391-402.

Pickel VM, Beckley SC, Joh TH, Reis DJ (1981) Ultrastructural immu- nocytochemical localization of tyrosine hydroxylase in the neostriatum. Brain Res 225:373-385.

Pickel VM, Johnson E, Carson M, Chan J (1992) Ultrastructure of spared dopamine terminals in caudate putamen nuclei of adult rats neonatally treated with intranigral 6-hydroxydopamine. Dev Brain Res 70:75-86.

Ragsdale CWJ, Graybiel AM (1988) Fibers from the basolateral nucleus of the amygdala selectively innervate striosomes in the caudate nucleus of the cat. J Comp Neurol 269:506-522.

Reynolds ES (1963) The use of lead citrate at high $\mathrm{pH}$ as an electronopaque stain in electron microscopy. J Cell Biol 17:208.

Rinaldi-Carmona M, Barth F, Heaulme M, Shire D, Calandra B, Cong C, Martinez S, Maruani J, Neliat G, Caput D (1994) SR 141716A, a potent and selective antagonist of the brain cannabinoid receptor. FEBS Lett 350:240-244.

Sagan S, Venance L, Torrens Y, Cordier J, Glowinski J, Giaume C (1999) Anandamide and W IN 55212-2 inhibit cyclic AMP formation through G-protein-coupled receptors distinct from CB1 cannabinoid receptors in cultured astrocytes. Eur J Neurosci 11:691-699.

Sánchez C, Galve-Roperh I, Canova C, Brachet P, Guzmán M (1998a) Delta ${ }^{9}$-tetrahydrocannabinol induces apoptosis in C6 glioma cells. FEBS Lett 436:6-10.

Sánchez C, Galve-Roperh I, Rueda D, Guzmán M (1998b) Involvement of sphingomyelin hydrolysis and the mitogen-activated protein kinase cascade in the Delta ${ }^{9}$-tetrahydrocannabinol-induced stimulation of glucose metabolism in primary astrocytes. Mol Pharmacol 54:834-843.

Sañudo-Peña MC, Walker JM (1998) Effects of intrapallidal cannabinoids on rotational behavior in rats: interactions with the dopaminergic system. Synapse 28:27-32.

Sañudo-Peña MC, Tsou K, Walker JM (1999) Motor actions of cannabinoids in the basal ganglia output nuclei. Life Sci 65:703-713.

Shapira M, Gafni M, Sarne Y (1998) Independence of, and interactions between, cannabinoid and opioid signal transduction pathways in N18TG2 cells. Brain Res 806:26-35.

Shen M, Piser TM, Seybold VS, Thayer SA (1996) Cannabinoid receptor agonists inhibit glutamatergic synaptic transmission in rat hippocampal cultures. J Neurosci 16:4322-4334.

Smith Y, Bevan MD, Shink E, Bolam JP (1998) Microcircuitry of the direct and indirect pathways of the basal ganglia. Neuroscience $86: 353-387$

Sonnewald U, Westergaard N, Schousboe A (1997) Glutamate transport and metabolism in astrocytes. Glia 21:56-63.

Stella N, Schweitzer P, Piomelli D (1997) A second endogenous cannabinoid that modulates long-term potentiation. Nature 388:773-778.

Svingos AL, Moriwaki A, Wang JB, Uhl GR, Pickel VM (1997) $\mu$-Opioid receptors are localized to extrasynaptic plasma membranes of GABAergic neurons and their targets in the rat nucleus accumbens. J Neurosci 17:2585-2595.

Szabo B, Dörner L, Pfreundtner C, Nörenberg W, Starke K (1998) Inhibition of GABAergic inhibitory postsynaptic currents by cannabinoids in rat corpus striatum. Neuroscience 85:395-403.

Szabo B, Mathonia WP, Pfreundtner C (2000) Cannabinoids inhibit excitatory neurotransmission in the substantia nigra pars reticulata. Neuroscience 97:89-97.

Takahashi KA, Linden DJ (2000) Cannabinoid receptor modulation of synapses received by cerebellar Purkinje cells. J Neurophysiol 83: 1167-1180.

Tsou K, Brown S, Sañudo-Peña MC, Mackie K, Walker JM (1998) Immunohistochemical distribution of cannabinoid $\mathrm{CB} 1$ receptors in the rat central nervous system. Neuroscience 83:393-411.

Twitchell W, Brown S, Mackie K (1997) Cannabinoids inhibit N- and $\mathrm{P} / \mathrm{Q}$-type calcium channels in cultured rat hippocampal neurons. J Neurophysiol 78:43-50.

Venance L, Piomelli D, Glowinski J, Glaume C (1995) Inhibition by anandamide of gap junctions and intercellular calcium signaling in striatal astrocytes. Nature 376:590-594.

Wang H, Moriwaki A, Wang JB, Uhl GR, Pickel VM (1996) Ultrastructural immunocytochemical localization of $\mu$-opioid receptors and Leu5-enkephalin in the patch compartment of the rat caudate putamen nucleus. J Comp Neurol 375:659-674.

Wang H, Gracy KN, Pickel VM (1999) $\mu$-Opioid and NMDA-type glutamate receptors are often colocalized in spiny neurons within patches of the caudate putamen nucleus. J Comp Neurol 412:132-146.

Wheeler DB, Randall A, Tsien RW (1994) Roles of N-type and Q-type $\mathrm{Ca}^{2+}$ channels in supporting hippocampal synaptic transmission. Science 264:107-111.

White NM, Hiroi N (1998) Preferential localization of self-stimulation sites in striosomes/patches in the rat striatum. Proc Natl Acad Sci USA 95:6486-6491. 